\title{
Social Darwinism in O'Neill's The Hairy Ape: Studies of the Modern Issues and Their Influences on American Society in the 1920s
}

\author{
Fatimah Saleh A Alhumoud \\ Independent Researcher \\ Hotat Bani Tamim; Riyadh, Saudi Arabia
}

\begin{abstract}
In the early 20s, O'Neill produced The Hairy Ape and introduced an account of the misrepresentation of proletariat states in American society. The article aims to demonstrate that The Hairy Ape is not only a play concerning the subject of social classes but also an application of Social Darwinism. It opens up new significant issue to highlight the exploitation, isolation, and alcohol prohibition and women's role in the society that affected all classes of society in the US. However, a social study proposed that Social Darwinism is the essence for illustrating social classes, the cause of class struggles, and changes to the status of women in America in the 1920s. This paper presents a novel finding that men, as workers, were adversely persecuted, growing numb to their human responses and emotions; they were personified as animals, devoid of intellectual thinking and acting on a level of basic instinct and pack mentality. Concurrent with the demise of male intellectualism and emotional awareness, there was an advance in the status of women; women flourished and experienced a growing sense of freedom in terms of fashion and voting.

Keywords: American society, proletariat, social classes, Social Darwinism, status, The Hairy Ape, women

Cite as: Alhumoud, F. S. A. (2020). Social Darwinism in O'Neill's The Hairy Ape: Studies of the Modern Issues and Their Influences on American Society in the 1920s. Arab World English Journal for Translation \& Literary Studies 4 (4).177- 186.

DOI: http://dx.doi.org/10.24093/awejtls/vol4no4.12
\end{abstract}




\section{Introduction}

Eugene O'Neill is a prominent playwright of twentieth-century American drama; however, he is not only an American dramatist but is also considered to equal some of the greatest European dramatists of the twentieth century, such as Bracket. The Hairy Ape was written in the early 1920s in the US. It consists of eight scenes, each of which is heavily influenced by the cogency of the '20s era. In view of this, it can be considered as O'Neill's masterpiece concerning the human identity and class struggles that shaped the lives of those living in the 1920s; it seemingly confirms the concept that the protagonist exists as one marginalized by a society in which he competes to uphold their ambitions, leading him into a spiral of despair and disintegration. However, this study specifically explores the consequences of Social Darwinism in America during the 1920s.

O'Neill as a significant dramatist depicts an image of American society in the 1920s. A Proper consideration of The Hairy Ape will reveal three questions. What are the causes of social Darwinism in American society? Why are workers considered inferior and unable to progress? What were the effects of social Darwinism on American women during the 1920s? To answer all these questions, the paper presents an original approach which a social analyse based on Social Darwinism theory to study American society during the 20s. Therefore, it is important to identify the reasons for the survival of the fittest in Americans and how it improves life. However, This paper is to address the causes behind the application of Social Darwinism in American society, more specifically the isolation and prohibition of alcohol, and the subsequent effect of these changes on society; namely, the creation of extreme distinctions in the social classes and the promotion of women's status in society. It is emphasized that O'Neill's The Hairy Ape "that the Social Darwinists might be right ... At the other is the search for more benign notions of evolution with which to counter the apparent claims of Darwinism. (The Irish Times, 2009, par.8)

\section{Literature Review}

Social Darwinism is a social ideology initiated in the late 1800s that adopted Charles Darwin's theory of evolution: The assumption that human life originated from joint ancestors, more specifically, apes. (Dawkins, 1993, p.84) suggests that "The word 'apes' usually means chimpanzees, gorillas, orangutans, gibbons, and siamangs. We admit that we are like apes, but we seldom realize that we are apes." In light of this, it is likely that the theory is based on the development of life from non-life and consists of natural selection or naturalistic descent with modification. Darwin's evolution theory is a slow process, as (Darwin, 1859, p.206) himself states that "natural selection acts only by taking advantage of slight successive variations; she can never take a great and sudden leap, but must advance by short and sure, though slow steps"

There are some the critic properly reflects the thoughts civilized Americans as they do not like to reach the concepts of humanity. For instance, a study by (Carthy, 1968, p.82) assumed that "Symbolically considered, The Hairy Ape is the blind cyclopean Demos that cannot build but only destroy; malformed, powerful when he stirs fair cities topple - thick-witted, dangerous, ugly" 
It was decided that the most effective method to adopt for this investigation was to illustrate the play by using social study. Social Darwinism is extremely impact The Hairy Ape. It is a science influenced by its social context, and it has been claimed that "Social Darwinism is a complex and controversial topic, a package of ideologies supposedly inspired by biological evolutionism that is of interest to scholars of both life and the social sciences"(bowler,2016,introduction). Furthermore, one should not overlook a claim by (Halliday, 1971, p.308-405) - that social Darwinism is a social theory founded by Herbert Spencer in 1860, derived from evolutionary theory. Social Darwinism led to a new understanding of the application of evolutionary theory to social thoughts and structures - from the concept of "survival of the fittest" originated the belief that the strongest and the fittest of society should flourish and survive, while the weak should be allowed to flounder and vanish.

The subject of Social Darwinism is based on the survival of the fittest, particularly in industrial capitalism, and has been a controversial and much-disputed matter within the field of literature. The Hairy Ape emphasizes the victimized modern industrial workers, enslaved by the high-class members of society. Although the extensive research carried out on this particular play demonstrates an apprehensive view of the oppression of the industrial classes and its causes, few studies exist that adequately cover the rising status of women in American society.

This paper reviews evidence for the effect of Social Darwinism in The Hairy Ape. It begins with a brief overview of the history of evolution and the reaction of American society towards it - a significant contributing factor in the origin of Social Darwinism. When society accepted this view, they assumed the principles and primary notion of the study. It also provides insight into American society's response to Social Darwinism.

\section{Discussion}

Social Darwinians as a notion spread in the US due to the popularity of Darwin beliefs. It is apparent that Darwin's theory, while greatly controversial, was originally neglected by the majority of American society, due to civil war, slavery, and modernization. However, it gained prominence in the second half of the 1800s, when the US permitted Darwin's evolution theory to be included in religious and scientific establishments. When Darwin's evolution theory was first published in 1859, people reacted differently to it; it created considerable arguments and debates among American scientists and thinkers. In 1870, American clerks and religious thinkers condemned evolutionary thinkers, generating impassioned debates between faith and evolution; they refused to accept the theory on intellectual grounds, as it posed a threat to their biblical beliefs and morality.

One of the most striking features of The Hairy Ape is that in the 1920s, Darwin's evolution theory was a component in the American curriculum, particularly in biology (Dixon, 2009, P.23) claimed that it was the religious debates of the theory that coincided with the rise of Americans' consciousness. The debates led to a division in American Protestantism, which preserved the essential foundation of faith; it divided into Liberal Protestantism (Modernist) and Evangelist. This 
disunity raised questions regarding the historical accuracy of biblical accounts and about new scientific thinking. Liberal Protestantism allowed scientific methods to enter into their religious doctrine, while Evangelists took a more conservative view on the matter. Since Darwin's theory of evolution is a controversial one, it has been divisive in Christianity's opposition to evolution; in the beginning, the evolution theory faced notable opposition. However, over time, Christians were content to participate in Darwin's theory within their biblical understanding. Today, Darwinism has become a pursuit of belief rather than one based on fact. According to (Dawkins, 1986, p. 6), "Darwinism made it possible to be intellectually fulfilled Atheist"

As has been previously stated, the concept of evolution is one based on scientific claims that humans are far-removed generations evolved directly from animal lineage, yet Spence the founder of Social Darwinism applies this concept to societal structure and thinking. Social Darwinism was a popular notion, created by British sociologist (Herbert Spencer, 1860) that spread rapidly in the US. It obtained great support among intellectuals and socialists. On his arrival to America, Spencer introduced his theory of Social Darwinism to American society; attending conferences and giving speeches, he claimed that there was no alternative to the survival of the fittest. In the US, some social reformers applied this theory in relation to recommendations to strengthen the government; this included applying its principles to justify racism. During the second American Industrial Revolution, the concept flourished, thriving as the US progressed from the industrial age of iron to that of steel, with the significant developments in steel, electricity, and oil.

Thru-out the last century, technical innovations have enabled people to live better and more productive lives. Humans have evolved thru time, and as we have evolved, so must or technology. Things would be quite difficult in 2012 if we were still relying on the technology from 1812. Innovation is part of the human spirit but is often oppressed due to the political situations one may be under.

(The Second Industrial Revolution and International Relations,2010,p.123)

This revolution propelled America from a society based in agriculture to one of industry. It irrevocably changed American society and brought with it complex economic and social changes. Engaging Social Darwinism in US policy and society during the isolation proved challenging and caused an imbalance in American society. The isolation occurred after the first World War (WWI), referring to the era as one where the League of Nations became involved in European alliances and wars according to (Day, P. J 1989,p.233)."America assumes that it can provide freedom and democracy by means not war. Thus, the American perspective is different from the European one." During the isolation period, America was predisposed to isolate itself economically from the world; more accurately, the politicians and the merchants ultimately opposed any alliance with Europe. The effects of the isolation were felt by the people of the era, as the bourgeois became richer, and the proletariat became poorer:

Arab World English Journal for Translation \& Literary Studies 
The widening of the economic gap between the poor and the wealthy is one of the most crucial problems that face social welfare... At the same time, people with wealth are consolidating their holdings, but less often in investment in either the human or the productive resources... These changes mean job loss and new poverty added to the old poverty. (Day, 1989, p. 2)

The Hairy Ape is not about a story of individuals; it is about cultural references and stereotypes; it reflects the American economic situation and its effect on society. More significantly, The Hairy Ape presents the struggle in American society under the concept of survival of the fittest. The notion claimed the strongest are the ones that survived - the upper and middle classes. This created an imbalance between the three parties; however, the imbalance of power between individuals, classes, and races was justified, as some people were considered fit to survive than others. The Hairy Ape is a criticism of the oppression of the proletariats by the bourgeoisie. (Alexander, 1953, p.390) asserts that the play:

Presents an extremely negative view of the state, of mechanized America, where the worker best adjusted to the system is a 'hairy ape,' and where the 'Capitalist class' is even more terribly dehumanized, for it has lost all connection with life, is simply 'a procession of gaudy marionettes.

The economic gap revealed that the working class and slaves were considered nothing more than apes. The title of The Hairy Ape alludes to the distinction of classes in the form of Yank, the protagonist, who is originally an impotent ape belonging to the zoo-he is a non-human, nonwhite savage. In actuality, he is a slave in pursuit of his identity. O'Neill is reported to have said that the play is to show how man, unable to feel the harmony with nature that as an animal he once knew, has not been able to establish a new harmony through sympathy with his own kind It is also observed that in an interview in 1922, O'Neill said, "Yank is really yourself, and myself" (Leech, 1963 p. 41). Yank does not belong to the ship, street, or five avenues, yet he is a primitive man who uncovers his identity in the zoo. O'Neill adds clarification to this by sending a letter to NY Herald Tribune of November 16/ 1924:

Yank can't go forward and so he tries to go back. This is what his shaking hands with the gorilla meant. But he can't go back to "belonging" either. The gorilla kills him. There is a large volume of published studies describing the role of a man and his struggle with his fate. The struggle used to be with the gods, but is now with himself, his past, and his attempt to "belong." (Clark, 1947, p. 84)

Yank has been expressed emotionally throughout the play; however, in the end, he succeeds in finding himself. He eventually abandons the human world as a refugee and recognizes himself in the animal home: "He slips on the floor and dies. The monkeys set up a chattering, whimpering wail. And, perhaps, the Hairy Ape at last belongs.'(O’Neill, 1922, p. 58) Nevertheless, the author 
portrays, "Yank is in his dirty dungarees... He has not shaved for days and around his... eyes - the black smudge of coal dust still sticks like make-up." ( O’Neill, 1922, p. 35)

First and foremost, it is considered that, for decades, Americans fought to find their position in the world. After WWI, people were pressed and despairing before they embarked on the industrialization that ultimately created the aforementioned social struggles. (Bogard 1972, p. 242) states that The Hairy Ape "deals with what may loosely be called 'anthropological' subject matter, expressed in terms of a search for the origins of life and referring to atavistic remnants of a primitive man appearing in modern society"

It cannot be denied that the concept of survival of the fittest can be applied to the relationship between the upper and working classes. Spencer defined the term as "the fittest will survive to out-reproduce the less fit by iteration and produce evolution" (Rosenberg, 2005, p.106). There was increased prosperity due to the explosion in innovation, stock market, and steel, but workers were extremely poor due to the oppression of the working classes - they were considered the weakness in the rewards of the American Economy. In the 1920s, America was a capitalist state in terms of class division; for instance, the working classes (like Yank) were afforded no freedom or power of speech to practice their political rights and beliefs. Moreover, they were given no liberation to escape from the working environment, with no support from the government. This is referred to as the laissez-faire attitude and meant no responsibility was taken for the lifestyle or conditions of the workers. Simultaneously, it provided opportunities and privileges that were only available to the upper classes.

The Hairy Ape exposes the struggle between the classes as Yank, the protagonist, represents the working class in a capitalist society. Yank embodied steel and was conscious that he was considered as nothing more than a machine made of steel: "I'm a busted Ingersoll, dat's what. Steel was me, and I owned the world. Now I ain't steel, and the wild owns me. Aw, hell! I can't see-it's all dark, get me? It's all wrong!" (O'Neill, 1922, p. 54) The working classes were employed to afford comfort to the higher classes. Here, an interpretation based on a social viewpoint depicts Yank as a miserable individual and as the hero of a "tragedy of the proletarian's exile from all the charms of culture" (Bab, 1931, p. 351). Moreover, regarding the significance of the ship in the play, the ship is dark, like that of a prison or cage from which the worker cannot escape. Yank is a working-class citizen; he is frightened, frail, struggles to define his identity, and has little hope of surviving. (O'Neill, 1922, p. 6) describes Yank in the opening scene as a beast in a cage: "The room is crowded with men, shouting, cursing, laughing, singing - a confused inchoate uproar swelling into a sort of unity, a meaning - the bewildered, furious, baffled defiance of a beast in a cage"

In addition to isolation, the prohibition of alcohol promoted the survival of the fittest (in America, during the 1920s, producing and purchasing alcohol was forbidden and illicit). There were four primary reasons to prohibit alcohol: Socially, after WWI, people believed that alcohol was damaging society, and they also thought it was inappropriate to enjoy alcohol while men were

Arab World English Journal for Translation \& Literary Studies 
fighting in the war; economically, banning alcohol assisted the American government in benefitting from a supplement of important grains, such as barley; religiously, alcohol goes against God's will, and societally, the prohibition of alcohol highlighted that fact that purchasing alcohol increased the income of the upper and middle classes. It is worth noting that Americans in The Hairy Ape do not drink alcohol due to the prohibition; the only character who is always drunk is Paddy, known as "Whiskey Johnny," (O’Neill, 1922, p. 9) and he is an old Irishman, not American. At this point, it is worth determining that the advancement of the role of women in American society can be related to the concept of survival of the fittest. Historically, women were housewives who played no role in the outside world. However, after WWI, the role of women rose in society; their role no longer restricted them to staying at home and taking care of their husbands and children. It was the first step in a long journey of earning their rights, but the recognition of women by the state and society can be viewed as a significant step forwards in the matter of survival at that time. In (Freedman, 1974, p.372-393) he further illustrated that, during WWI, men left their jobs to serve their country in the war overseas, and women replaced their jobs. In other words, they joined the world of work and employment and became independent, both financially and literally.

Moreover, it was the first time women were afforded the right to vote. As politics is an essential constituent of every woman's movements, American feminists urged that women should have equal rights to men and be considered women with full citizenship. After many years fighting for their political rights, it was finally legalized in the 1920s: "on August 18, 1920, the 19th Amendment to the Constitution was ratified. And on November 2 of that year, more than 8 million women across the United States voted in elections for the first time" (Women's Suffrage, 2009, conclusion).

The 1920s were the first time that women experienced fewer restrictions regarding clothing. Many women admired fashion and beauty; they designed their costumes while considering the traditionalism and rules imposed by society. For example, a woman wearing shorts in the Victorian era would be disgraced. However, the 1920s were the commencement of modernization in clothing and fashion and is often referred to as twenties fashion. Styles became more fashionable, and women were no longer wearing long skirts or loose clothing that hid their figures: "Fashion was one of several industries that expanded rapidly to meet their demands... rising hemlines, sportswear, and even trousers made their generation physically freer than any in modern history."(Markell, 2018, par.5) Moreover, a biological study regarding the survival of the fittest can be applied to the role of women: ।

Women have long known that they are not the "weaker sex," but a University of Washington anthropologist says he has proved it. It is not just that women live longer when the going is good. Women are also more likely than men to survive when conditions are at their worst.

(Brody, 1996, par.1)

Arab World English Journal for Translation \& Literary Studies 
In a critique of what has been quoted above that rather than invoking biological reasons, it would emphasize cultural factors, such as work patterns, that might have been relevant to women's superior survival (Sex and the Survival of the Fittest: Calamities Are a Disaster for Men, 1996, p.10) Employing this study regarding the changes in the status of women demonstrates that women are more than adequately powerful enough to survive both biologically and socially. During the 1920s, women acquired the necessary gender equality in their essential rights, work, and voting to cease being considered sub-standard, without which they would not survive. The main survival character in The Hairy Ape is that of Mildred; despite her comfortable and privileged financial situation, she is strong and resilient enough to survive in male society. She is a beautiful young woman, appropriate for the upper class. She is also a social activist who demands equality and displays empathy for the lower classes; however, she still refers to Yank as a "filthy beast." (O’Neill, 1922, p. 26) Also, O'Neill characterizes Mildred privileged qualities as a woman and upper-class member: (O’Neill, 1922, p. 17) states:

A section of the promenade deck. MILDRED DOUGLAS and her aunt are discovered reclining in deck chairs. The former is a girl of twenty, slender, delicate, with a pale, pretty face marred by a self-conscious expression of disdainful superiority... In the midst of this, these two incongruous, artificial figures, inert and disharmonious, the elder like a gray lump of dough touched up with rouge, the younger-looking as if the vitality of her stock had been sapped before she was conceived, so that she is the expression not of its life energy but merely of the artificialities that energy had won for itself in the spending.

Although The Hairy Ape is a contemporary tragedy, it doesn't relate man with the idea of spirituality, fate or destiny as ancient Greek tragedies. The results might suggest the representation of inhuman forces of modern civilization which is simplified in Social Darwinism. However, based on the findings of similar studies such as (Carthy1968, p.82), a more plausible explanation is that the Hairy ape has presented a negative perspective early modern world and the mechanical era. It has been discussed that the blue collar is severely mistreated like Yank the protagonist whereas the upper class is dehumanized the workers that cause the lost a great connection within the life itself. On the contrary, the result provides a new insight into the relationship between the survival of the fittest and women. Women in the 20 s gain more right, voting and become fashionable.

\section{Conclusion}

In conclusion, The Hairy Ape specifically explores the consequences of Social Darwinism in America during the 1920s. Yank lost his sense of harmony with nature and identity in the modern world; subsequently, he finds himself at the zoo, talking to an ape. It is this loss of a sense of belonging that the poorer classes experienced in the 1920s. It was the era of steel and manufacturing, a time of progression, but it was not the time of freedom and belonging for the lower classes. Industrialism deprived the working class of their spiritual values and humanity. Social Darwinism is reflected by presenting the main issue: oppression over the industrial worker by members of the upper classes in a capitalist country. The struggles addressed were imposed by

Arab World English Journal for Translation \& Literary Studies 
the isolation and the prohibition of alcohol, highlighting the concept of the survival of the fittest. The isolation in the 20s increased the class gab; the rich built more industries and employed the blue collar to do sever works. Furthermore, the role of women is implicitly associated with the concept of the survival of the fittest - the women of that era were strong enough to survive. They initiate core of independency. Women became workers in the industry due to the WWI then they rejected not to have a voice to demand more rights.

\section{About the Author:}

Fatimah Saleh A Alhumoud has got an MA English Literature with three years of experience teaching English as a second language in higher education. She is interested in searching for feminist, historical, psychological analyses in literature. However, she seeks to perform academic research and high quality of teaching. https://orcid.org/0000-0002-4863-5051

\section{References:}

Aaron, Paul, and Musto, David. (1918) Temperance and Prohibition in America: An Historical Overview. In: Moore, Mark H., and Gerstein, Dean R., (eds.) Alcohol and Public Policy: Beyond the Shadow of Prohibition. Washington, DC: National Academic Press, Pp. 127180

Alexander, D. (1954). Eugene O'Neill as Social Critic. American Quarterly, 6(4), 349-363. doi: $10.2307 / 3031370$

Bab, J. (1931). As Europe Sees America's Foremost Playwright. The Theatre Guild Magazine, Nov.1931 350-352.

Bannister, R. (2007). Social Darwinism. Microsoft Encarta Online Encyclopedia. Available at https://works.swarthmore.edu/fac-history/408

Bogard, (1972.) Contour in Times: The Plays of Eugene O'Neill. New York: Oxford University Press.

Bowler, (2016). Social Darwinism. obo in Sociology. doi: 10.1093/obo/9780199756384-0166

Brody, J. E. (1996). Sex and the Survival of the Fittest: Calamities Are a Disaster for Men. New York Times.Par.1

Carthy, D, M., (1968). Hairy Ape or Bronge Ajax in Chester Clayton Long. The Role of Nemises in the structure of Selected Plays of Eugene O'Neill. The Hague: Monton \& Co, Publishers.

Clark, (1947). Eugene O;Neill: The Man and His Plays. New York: Dover.

Darwin, Charles, (1859). On the origin of species by means of natural selection, or preservation of favoured races in the struggle for life. London: John Murray,

Dawkins, Richard (1986). The Blind Watchmaker. New York: Norton.

Dawkins, Richard.(2016) "Gaps in the Mind", at Paola Cavalieri \& Peter Singer (eds.) The Great Ape Project: Equality Beyond Humanity. St Martin's Griffin, 199

Day, P. J. (1989). The New Poor in America: Isolationism in an International Political Economy. Social Work, 34(3), 227-232. https://doi.org/10.1093/sw/34.3.227

Dixon, T. (2009). America's Difficulty with Darwin. History Today, 59(2), 22-28.

Arab World English Journal for Translation \& Literary Studies 
Dowling, R. M. (2009). Critical Companion to Eugene O'Neill: A Literary Reference to His Life and Work. New York: Infobase Publishing.

Freedman, E. B. (1974). The New Woman: Changing Views of Women in the 1920s. The Journal of American History, 61(2), 372-393.

Halliday, R. J. (1971). Social Darwinism: A Definition. Victorian Studies, 14(4), 389- 405.

History.com. (2009). Women's Suffrage. Available at www.history.com/topics/womenshistory/the-fight-for-womens-suffrage

How Darwin Helped Shape Irish Writing. (2009). The Irish Times. Available at https://www.irishtimes.com/news/how-darwin-helped-shape-irish-writing-1.705483

History.com. (2009). Women's Suffrage. Available at www.history.com/topics/womenshistory/the-fight-for-womens-suffrage

Leech, Clifford (1963). O'Neill. Edinburgh and London: Oliver and Boyd.

Mackrell, J. (2018). The 1920s: Young women took the struggle for freedom into their personal lives. The Guardian. Available at www.theguardian.com/lifeandstyle/2018/feb/05/the-1920syoung-women-took-the-struggle-for-freedom-into-their-personal-lives

O'Neill, E. (1922). The Hairy Ape. The Project Gutenberg. Retrieved 2020, from https://fb2bookfree.com/uploads/files/2020-03/1585323438_the-hairy-ape-by-eugeneoneill.pdf

Rosenberg E, (2005): The evolution of animals and plants via symbiosis with microorganisms. $\quad$ EnvironMicrobiolRep. 2010;2(4):500-6. 10.1111/j.17582229.2010.00177.x

Singer, P., \& Cavalieri, P. (Eds.). (1993). The Great Ape Project. St. Martin's Griffin.

The Development of Foreign Policy. (2015). Office of the Historian. US Department of State.

The Guardian (2015) Review of The Hairy Ape review - Carvel is a man of steel. Available at www.theguardian.com/stage/2015/nov/01/hairy-ape-eugene-oneill-bertie-carvelobserver-review

The Second Industrial Revolution and International Relations. (2010). 123 Help Me.

Herbert Spencer, (The Stanford Encyclopedia of Philosophy Edward N. Zalta (ed.), URL = $<$ https://plato.stanford.edu/archives/fall2019/entries/spencer/> 